\title{
Antibiotic Activity of Endophytic Bacteria isolated from Euchema cottoni of North Galesong Sea, Takalar
}

\author{
Hafsan', Isna Rasdianah Aziz², Eka Sukmawaty ${ }^{3}$, St. Aisyah S4, Hasyimuddin ${ }^{4}$, \\ Zulkarnain $^{6}$, Hajrah $^{7}$ \\ ${ }^{1234567}$ Department of Biology, Faculty of Science and Technology, Universitas Islam Negeri \\ Alauddin Makassar, Indonesia. 92113 \\ \{hafsan.bio@uin-alauddin.ac.id ${ }^{1}$, isna-rasdianah@uin-alauddin.ac.id²\}
}

\begin{abstract}
Aeromonas sp. and Klebsiella sp. were two active endophytic microbe isolated from Euchema cottoni in North Galesong Sea, Takalar district using agar nutrient medium. These isolates then purified by the strike plate on Klinger Iron Agar medium. Fermentation process was carried out using yeast malt broth medium to provide the active compound. The fermented product were supernatant and pellets. The antimicrobial activity was measeured using agar diffusion method. The result show that supernatan which only gave activity to Staphylococcus aureus and Escherichia coli is Aeromonos sp.
\end{abstract}

Keywords: Aeromonas sp., Antibiotic, Endophytic bacteria, Klebsiella sp., Seaweed.

\section{Introduction}

Endophytes, microbes which perform ecological function in a plant, complete their life cycle and limit pathogen damage within host plant tissue. Plant-specific or complex interaction with endophytic microbes involves virtually the entire spectrum of mutualistic association, in which plant releases an array of chemical cues as nutrient source for microbe, while microbes transform bioactive compound to promote their host-plant growth and development [1][2][3][4].

Metabolic products, antibiotics, are typically excreted by microbes at limited level that inhibit or kill other microbes. Several genera of Pseudomonas viridiflava, Taxomyces andreanae, Streptomyces sp., Muscodor sp., Aspergillus niger, Artemisia annua, Neurospora sp., and Pestalotiopsis sp. are well-known endophytic microbes that produce secondary metabolites as antiinsects [5][6], anticancer and antitumour [7][8][9], antifungal [10][9], antiinflammatory [11], antidiabetic [12], antiviral [13], antihelminthic [14], and antimalarial [15][16]. These can be explored prospectively as certain remedies for particular diseases.

Eucheuma cottonii is a widely seaweed cultivated by farmers in North Galesong sea, a subdistrict in Takalar district, South Sulawesi. Seaweed becomes a mainstay commodity of Takalar regency, which provides $36.5 \%$ of national production, as the third largest national contribution in Indonesia [17][18]. This high production provides an engagement in bioprospecting that endophytic microbes have potential sources of natural product in holding for novel antibiotic discovery. Thus, the synergistic effect against resistant microbe leads to new choices for the treatment of certain diseases. A need for intense and prolonged use of antibiotics in Indonesia, 
the discovery and development of new antibiotics remain to address the one important target that ensures new resource for drug discovery.

Based on its potential, it is necessary to evaluate antibiotic activity of endophytic microbes isolated from Eucheuma cottonii, especially in North Galesong Sea.

\section{Material and Methods}

\subsection{Pure culture fermentation of endophytic microbe}

Pure culture colonies from previous studies (code A1 and A2, not discussed in this study) were taken 1 ose, inoculated in nutrient agar, then incubated at $37^{\circ} \mathrm{C} 24$ hours, while on potato dextrose agar, it's incubated at $28^{\circ} \mathrm{C}$ for 5 days. The suspension was carried out with $2 \mathrm{ml} 0.9 \%$ $\mathrm{NaCl}$ and inoculated in $10 \mathrm{ml}$ of yeast malt broth liquid. $2 \mathrm{ml}$ inoculum was pipetted and put in containing $10 \mathrm{ml}$ of YM-Broth, incubated at $28^{\circ} \mathrm{C}$ for 24 hours, and shaken at $200 \mathrm{rpm}$.

\subsection{Cell reculture and antibiotic activity test}

Staphylococcus aureus and Escherichia coli (experimental strains) were taken 1 ose and then inoculated on natrium agar, then incubated at $37^{\circ} \mathrm{C} 24$ hours. Microbial suspension was put $1 \mathrm{ml}$ into nutrient agar and potato dextrose agar, homogenized and then left $15 \mathrm{~min}$ to half solidify. the soaked paper disc is laid with aseptic fermented filtrate, incubated on nutrient agar at $37^{\circ} \mathrm{C} 24$ hours, while $28^{\circ} \mathrm{C}$ for 5 days on potato dextrose agar. The inhibitation zone is seen as a clear zone around the disk containing the results of fermentate. The diameter of the clear zone formed was measured and recorded as an active isolate.

\subsection{Biochemical activity test}

2.3.1 Kligers Iron Agar test. Isolate was taken 1 ose, streak to the surface of the agar slant, then incubated at $37^{\circ} \mathrm{C} 24$ hours.

2.3.2 Motility test. Isolates were taken 1 ose, inoculated vertically until mid-medium, then incubated at $37^{\circ} \mathrm{C} 24$ hours.

2.3.3 Indol test. Isolates were taken 1 ose, inoculated into medium then homogenized. After incubation at $37^{\circ} \mathrm{C} 24$ hours, Ehrlich reagents were added in one drop to the tube.

2.3.4 Methyl red test. Isolates were taken 1 ose, inoculated into medium, homogenized, then incubated at $37^{\circ} \mathrm{C} 24$ hours, one drop of methyl red indicator were added to the tube.

2.3.5 Voges-Proskauer test. Isolates were taken 1 ose, inoculated into medium, homogenized, incubated at $37^{\circ} \mathrm{C} 24$ hours, then $\alpha$-naphthol and $\mathrm{KOH}$ were added to the tube.

2.3.6 Citrate test. Isolates were taken 1 ose, streak to the agar slant for citrate test, then incubated at $37^{\circ} \mathrm{C} 24$ hours

2.3.7 Urea test. Isolates were taken 1 ose, streak to the agar slant for urea test, then incubated at $37^{\circ} \mathrm{C} 24$ hours

2.3.8 Carbohydrate test. This test used several medium: glucose, lactose, sucrose, maltose, mannitol and malonate. Isolates were inoculated to each medium, homogenized, then incubated at $37^{\circ} \mathrm{C} 24$ hours.

2.3.9 Lysine test. Isolates were taken 1 ose, inoculated into lysine medium, homogenized, then incubated at $37^{\circ} \mathrm{C} 24$ hours 
2.3.10 Catalase test. Isolates were taken 1 ose and put on clean glass object, then added with $3 \% \mathrm{H}_{2} \mathrm{O}_{2}$ reagent to characterize the bubble formation

\section{Results and Discussion}

Pure isolates are fermented using yeast malt broth for 24 hours while being shaken with a shaker incubator at $200 \mathrm{rpm}$, thus separating into two parts. Yeast malt broth is a liquid medium containing yeast extract as a protein source, maltose and dextrose as a carbon source and peptone as an amino acids source, which are needed by bacteria for growth, cell synthesis, energy requirements in metabolism and movement. Physiological salt solution $(0.9 \% \mathrm{NaCl})$ maintains the osmotic balance and protect the cell wall of bacteria from such osmotic rupture and contraction as ideal ionic strength [19][20]. Shaking process at $200 \mathrm{rpm}$ for 24 hours maintain the microbe life by producing the secondary metabolites as an early stage of growth that may coordinate competitive microbe repression. The antimicrobial substance active against competitive bacteria was called antibiotics, as signaling agents instead of weapons. For this study, antibiotic activity test was conducted to explore the potential of secondary metabolism result in endophytic microbe isolated from $E$. cottonii.

Antimicrobial activity was carried out using Staphylococcus aureus representing grampositive bacteria and Escherichia coli as gram-negative bacteria. Selection of both experimental strains due to their pathogenicity through invasiveness, toxins, and antibiotic resistance. $S$. aureus is opportunistic pathogens colonized skin and membranes, then cause a wide range of diseases, including abscesses, pneumonia, meningitis, urinary tract infections, and food poisoning, whereas $E$. coli are the main cause of chronic diarrhea. Isolates that showed activity against microbial were A1, Aeromonas sp., while A2 isolates produced were Kleibsella sp.

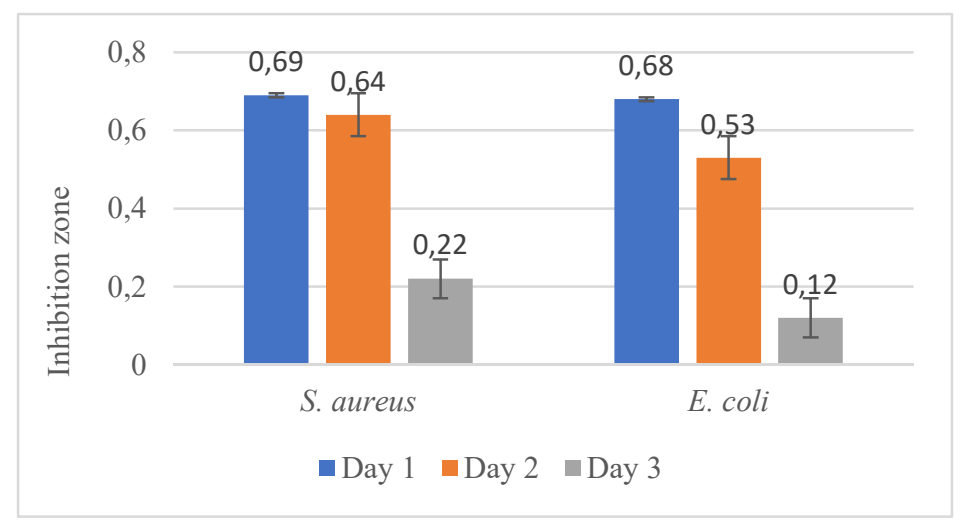

Fig 1. Inhibition zone of isolate A1

Antibiotic activity was carried out by diffusion agar using nutrient agar. Inhibitory zones formed around the paper disk shows that secondary metabolites of isolate A1 have an inhibitory effect on $S$. aureus and E. coli. After incubation in day 1 for 24 hours (figure 1), isolate A1 gave inhibition to $S$. aureus with $0.69 \mathrm{~cm}$ (average), compared to E. coli with $0.68 \mathrm{~cm}$ (average). On the second day with incubation period of 48 hours, the diameter of the inhibitory zone was reduced as seen from the clear zone around the paper disk, in $S$. aureus showed $0.64 \mathrm{~cm}$ (average), while in E. coli was $0.53 \mathrm{~cm}$ (average). The third day of 3 x 24 hours incubation, isolates did not inhibit at all, hence there was no clear area around the paper disk as seen in the 
$S$. aureus test with $0.22 \mathrm{~cm}$ (average) while in $E$. coli, the inhibition decreases in $0.12 \mathrm{~mm}$ (average). Comparison of inhibition zones from the first to the third day has decreased due to optimum point during the incubation period of 24 hours. Cell development was increasing day by day until nutrients depletion in medium, thus bacteria have low ability to inhibit microbes around.

Table 1. Biochemical activity test of endopyhtic microbe

\begin{tabular}{|c|c|c|}
\hline Biochemical activity test & A1 & A2 \\
\hline KIA & AL/A -/- & $\mathrm{A} / \mathrm{A}+/-$ \\
\hline Motility & - & + \\
\hline Indol & - & - \\
\hline Ornitri & - & - \\
\hline Urea & - & + \\
\hline Citrate & - & + \\
\hline MR & - & $\mathrm{V}$ \\
\hline VP & - & - \\
\hline Glucose & + & + \\
\hline Lactose & + & + \\
\hline Sucrose & + & + \\
\hline Maltosa & + & + \\
\hline Manitol & + & + \\
\hline Malonat & - & + \\
\hline LIA & - & - \\
\hline $3 \mathrm{~S}$ & $\mathrm{~V}$ & - \\
\hline $\mathrm{O}$ & - & - \\
\hline $\mathrm{F}$ & - & - \\
\hline PAD & - & - \\
\hline Catalase & + & + \\
\hline
\end{tabular}

KIA test provides that isolate A1 are able to ferment glucose while A2 ferment lactose and sucrose. Isolates showed negative results marked by no black formation around the inoculation area. The black does not form due to the absence of $\mathrm{H}_{2} \mathrm{~S}$ gas. Motility test showed a positive isolate A2 characterized by spread growth, indicating isolate were motile, while isolate A1 were negative. Urea test showed that the positive A2 isolate was marked by a change in color from red-orange to red-purple, indicating the occurrence of urea hydrolysis. The citrate test showed isolate A1 was negative, whereas in positive A2 isolate with a marked change in green to blue. Microbes were able to use citrate as the only carbon source. MR and VP test for all isolates showed negative results. This test shows whether glucose can be converted to acetone, hence the medium added with alpha-naphthol and $\mathrm{KOH}$ reagent, will produce red, the bacteria succesfully produce acetone.

Carbohydrate fermentation test provided positive result of isolate A1 and A2 with gas formation in the durham tube. LIA test is decarboxylase of carboxyl groups from organic molecule where lysine is an amino acid. The acid was produced in the glucose fermentation which reduces the $\mathrm{pH}$ of the media. The role of the lysine decarboxylation reactions would favour the amino formation by acid neutralizing, seen in color changes from yellow to purple. 
All isolates showed negative result of this test. PAD test also showed negative result of both isolates. After several biochemical tests, it was known that endophytic microbes that could produce antibiotics from E. cottonii were Aeromonas sp. by showing inhibitory zones in their antibiotic activity tests.

\section{Conclusion}

Endophytic microbes from marine algae Eucheuma cottonii found in North Galesong Sea produce one isolate, Aeromonas sp.

\section{References}

[1] P. R. Hardoim et al., "The Hidden World within Plants: Ecological and Evolutionary Considerations for Defining Functioning of Microbial Endophytes," Microbiol. Mol. Biol. Rev., vol. 79, no. 3, pp. 2261-2268 (2015). doi: 10.1128/MMBR.00050-14

[2] A. E. Arnold et al., "Fungal endophytes limit pathogen damage in a tropical tree," Proc. Natl. Acad. Sci., vol. 100, no. 26, pp. 15649-15654 (2003). doi: 10.1073/pnas.2533483100

[3] D. V Badri, T. L. Weir, D. Lelie, van der, and J. M. Vivanco, "Rhizosphere chemical dialogues: plant-microbe interactions," Curr. Opin. Biotechnol., vol. 20, no. 6, pp. 642650 (2013). doi: 10.1016/j.copbio.2009.09.014

[4] G. A. Strobel, "Endophytes as sources of bioactive products," Microbes Infect., vol. 5, no. 6, pp. 535-544 (2003). doi: 10.1016/S1286-4579(03)00073-X

[5] Y. J. Cardoza, K. D. Klepzig, and K. F. Raffa, "Bacteria in oral secretions of an endophytic insect inhibit antagonistic fungi," Ecol. Entomol., vol. 31, no. 6, pp. 636-645 (2006). doi: 10.1111/j.1365-2311.2006.00829.x

[6] M. C. González, A. L. Anaya, A. E. Glenn, M. L. Macías-Rubalcava, B. E. HernándezBautista, and R. T. Hanlin, "Muscodor yucatanensis, a new endophytic ascomycete from Mexican chakah, Bursera simaruba," Mycotaxon, vol. 110, no. 1, pp. 363-372 (2009).

[7] J. Li et al., "Antitumour and antimicrobial activities of endophytic streptomycetes from pharmaceutical plants in rainforest," Lett. Appl. Microbiol., vol. 47, no. 6, pp. 574-580 (2008). doi: 10.1111/j.1472-765X.2008.02470.x

[8] R. K. Tenguria and F. N. Khan, "Distribution of Endophytic Fungi in Leaves of Azadirachta indica A. JUSS. (Neem) of Panchmarhi Biosphere Reserve," Curr. Bot., vol. 2, no. 2, pp. 27-29 (2011).

[9] Y. Huang, J. Wang, G. Li, Z. Zheng, and W. Su, “Antitumor and antifungal activities in endophytic fungi isolated from pharmaceutical plants Taxus mairei, Cephalataxus fortunei and Torreya grandis," FEMS Immunol. Med. Microbiol., vol. 31, no. 2, pp. 163-167 (2001). doi: 10.1111/j.1574-695X.2001.tb00513.x

[10] C. H. Liu, W. X. Zou, H. Lu, and R. X. Tan, "Antifungal activity of Artemisia annua endophyte cultures against phytopathogenic fungi," J. Biotechnol., vol. 88, no. 3, pp. $277-$ 282 (2001). doi: 10.1016/S0168-1656(01)00285-1

[11] T. Taechowisan, A. Wanbanjob, P. Tuntiwachwuttikul, and J. Liu, "Anti-inflammatory activity of lansais from endophytic Streptomyces sp. SUC1 in LPS-induced RAW 264.7 cells," Food Agric. Immunol., vol. 20, no. 1, pp. 67-77 (2009). doi: $10.1080 / 09540100902730064$

[12] V. J. Akshatha, M. S. Nalini, C. D’Souza, and H. S. Prakash, "Streptomycete endophytes from anti-diabetic medicinal plants of the Western Ghats inhibit alpha-amylase and promote glucose uptake," Lett. Appl. Microbiol., vol. 58, no. 5, pp. $433-439$ (2014). doi: 
10.1111/lam.12209

[13] P. Wang et al., "Diketopiperazine Derivatives from the Marine-Derived Actinomycete Streptomyces sp. FXJ7.328," Mar. drug, vol. 11, no. 4, pp. 1035-1049 (2013). doi: $10.3390 / \mathrm{md} 11041035$

[14] S. Ōmura et al., "An anthelmintic compound, nafuredin, shows selective inhibition of complex I in helminth mitochondria," Proc. Natl. Acad. Sci., vol. 98, no. 1, pp. 60-62 (2001). doi: 10.1073/pnas.98.1.60

[15] M. S. Baba et al., "In vivo antimalarial activity of the endophytic actinobacteria, Streptomyces SUK 10," Microb. Physiol. Biochem., vol. 53, no. 12, pp. 847-855 (2015). doi: $10.1007 / \mathrm{s} 12275-015-5076-6$

[16] S. Wiyakrutta et al., "Endophytic fungi with anti-microbial, anti-cancer and anti-malarial activities isolated from Thai medicinal plants," World J. Microbiol. Biotechnol., vol. 20, no. 3, pp. 265-272 (2004). doi: 10.1023/B:WIBI.0000023832.27679.a8

[17] A. Rahadiati, K. Soewardi, Y. Wardiatno, and D. Sutrisno, "Pemetaan sebaran budidaya rumput laut: pendekatan analisis multitemporal (studi kasus di kabupaten Takalar Sulawesi Selatan)," Maj. Ilm. Globe, vol. 20, no. 1, pp. 13-22 (2018).

[18] K. Yaqin, I. Burhanuddin, and W. Samad, "Biodiversity of seaweed and their metal contents from littoral zone of South Sulawesi waters," Semin. Int. Kelautan, Univ. Udayana Bali, pp. 1-16 (2011).

[19] D. K. Maheshwari, Bacterial Diversity in Sustainable Agriculture. Switzerland: Springer, Cham, (2014). doi: 10.1007/978-3-319-05936-5

[20] R. D. Sleator and C. Hill, "Bacterial osmoadaptation: the role of osmolytes in bacterial stress and virulence," Microbiol. Rev., vol. 26, no. 1, pp. 49-71 (2002). doi: 10.1111/j.1574-6976.2002.tb00598.x 